\title{
Tekijän identiteetti taloussanomalehtien pääkirjoituksissa
}

\author{
Pääkirjoitustoimittajan sosiaalisesta \\ roolista tuotettu, teksteistä tulkittu
}

Heli KATAJAMÄKI

\section{Väitöksenalkajaisesitelmä Vaasan yliopistossa 17. marraskuuta 2018}

Syyskuun 4. päivänä vuonna 2001 Kauppalehden pääkirjoituksen otsikkona oli $J a$ pani sukeltaa syvälle. Kokenut talouslehtien lukija ymmärtää, että Japanilla viitataan valtioon ja 'sukeltaja' ei ole elollinen, vaan eloton Japanin talous. Lukija tunnistaa sanan sukeltaa pääkirjoituksessa metaforaksi ja ymmärtää, että sanalla tarkoitetaan Japanin talouden 'laskemista' eikä 'veden alla uimista'. Kuvattavana on siten taloudellisista tilastoluvuista tehty päätelmä, joka hahmotetaan graafisena, laskevana käyränä. Otsikko on tulkittavissa negatiiviseksi arvottamiseksi, kun tunnetaan diskurssiyhteisössä jaettu olettamus kansantalouksien pyrkimisestä taloudelliseen hyvinvointiin, jota toisiinsa sidoksissa olevien kansantalouksien taloudellinen kasvu edistää. Siksi Suomen kansantalouden näkökulmasta myös Japanin talouden lasku on huono asia. Otsikko havainnollistaa, miten tekstissä tuotettujen merkitysten ymmärtäminen perustuu yksittäisten sanojen lisäksi lauseyhteyteen ja tekstin ulkopuoliseen kontekstiin. Siten lukijan tietämys tekstin ulkopuolisesta kontekstista, esimerkiksi tekstin kirjoittajien ja lukijoiden jakamasta arvo- ja uskomusjärjestelmästä eli ideologiasta, ohjaa merkitysten ymmärtämistä.

Arvottavat merkitykset ovat suhtautumisen teorian (appraisal theory, Martin \& White 2005) mukaan yksi niistä keinoista, jotka ilmaisevat tekijän suhtautumista sanottuun. Sama tehtävä on myös ohjeistamista ja sitoutumista ilmaisevilla keinoilla. Väitöstutkimuksessani olen tarkastellut, millä tavalla arvottavilla, ohjeistavilla ja sitoutumisen merkityksillä tuotetaan tekijän identiteettiä. Tutkimuksessani olen vastannut kysymykseen, millainen käsitys tekstin tekijästä eli tekijän identiteetistä tekstistä syn- 
tyy taloussanomalehtien pääkirjoituksien merkitysten kautta. Tämän lisäksi tutkimustani on vienyt eteenpäin kysymys, miksi teksti on kirjoitettu niin kuin on. Vastauksia olen etsinyt kahdella eri tavalla: haastattelemalla pääkirjoitusten toimittajia ja analysoimalla pääkirjoituksia. Aineistona ovat kolmen kokeneen pääkirjoitustoimittajan haastattelut ja 32 kehityskulkua kuvaavaa pääkirjoitusta, joita kutsun kehitysteksteiksi. Aineiston Kauppalehden pääkirjoitukset ovat vuosilta 2001, 2005 ja 2015 ja Taloussanomien pääkirjoitukset vuosilta 2001 ja 2005. Haastatteluaineiston ja tekstiaineiston analysointi on antanut omat vastauksensa, joita tutkimuksen lopussa keskustelutan keskenään.

Toimittajakeskeisen lähestymistavan takia tutkimuksen teoreettisena lähtökohtana on toiminut Swalesin (1990) ja Bhatian (1993, 2004) kehittelemä ammattikielen tutkimuksen tekstilajiteoria. Teorian kautta on ollut mielekästä yhdistää toimittajan näkemysten ja tekstien analysointi. Vaikka tämä on muodostanut yleisimmän teoreettisen kehyksen tutkimukselleni, tutkimus on ennen kaikkea diskurssiteoreettinen, sillä tutkimuksen kielikäsitys nojautuu diskurssianalyyttisiin teorioihin ja tutkimuksen analyyseissä tarkastellaan erityisesti kielen käyttöä. Ammattikielen tutkimuksen tekstilajiteorian lisäksi nojaan tutkimuksessani Faircgloughin (esim. 2003; 2006) kriittiseen diskurssianalyysiin ja Martinin ja Whiten (2005) kehittelemään suhtautumisen teoriaan.

Taloussanomalehtien pääkirjoitukset nähdään tutkimuksessani tekstin toimittajien ja lukijoiden yhteisöä ylläpitäväksi viestinnän välineeksi. Tällöin voidaan puhua diskurssiyhteisöstä (ks. Swales 1990: 24; Luukka 1995: 69-70), sillä diskurssiyhteisö rakentuu tekstien kautta. Tässä tapauksessa yhteisöä rakentavat taloussanomalehtien eri tekstit, joilla pyritään viestimään lukijaa kiinnostavalla tavalla. Teksti on ainutkertainen viestintätapahtuma, jossa tekijän identiteettiä tuotetaan tekstiin valittujen merkitysten kautta. Mediassa tekstejä tuotetaan päivittäin, ja niitä kirjoitetaan tänään hieman samoin kuin eilenkin. Näin syntyy tapoja tuottaa tekstejä ja käyttää kieltä, mutta myös tapoja ymmärtää niitä suhteessa aiemmin luettuun. Lukijalle syntyy odotuksia siitä, miten näissä teksteissä puhutaan. Käytäntöjen vakiintuessa vakiintuvat myös sosiaaliset roolit, joista tekstejä tuotetaan. Tutkimuksessani lähestyn pääkirjoituksia kahdesta suunnasta. Yhtäältä tarkastelen diskurssiyhteisön vakiintuneena käytäntönä tekijän omaksumaa sosiaalista roolia, josta tekijän identiteetti teksteihin tuotetaan. Toisaalta teksteissä rakentuvaa ja sosiaalista roolia tuottavaa tekijän identiteettiä tarkastelen diskurssiyhteisön ainutkertaisina viestintätapahtumina, kielenkäyttönä. Samankaltaisuutta teksteihin tuo juuri sama tekstilaji ja se, että sitä tuottavilla pääkirjoitustoimittajilla on tekstilajitietoa siitä, millaisesta sosiaalisesta roolista tietyn tekstilajin teksti tuotetaan. Tekstilajitieto kattaa sen, mihin tekstillä voidaan pyrkiä, millaisesta asemasta teksti tuotetaan, millaisia ihanteita tekstillä vahvistetaan, ketä sillä yritetään mielistellä, kenet halutaan vakuuttaa, kehen sillä halutaan vaikuttaa ja mitkä ovat sopivia aiheita ja aiheen käsittelytapoja.

Väitöstutkimukseni tuo esille, millaisilla kielellisillä keinoilla merkityksiä tuotetaan. Suhtautumisen teoriaan nojautuen kuvaan, millaisia tuotetut merkitykset ovat ja mihin ne kohdistuvat. Tarkastelemissani pääkirjoituksissa asiat esitetään usein faktuaalisina väitelauseina, mutta lisäksi niissä käytetään monipuolisesti erilaisia sitoutumista ilmaisevia keinoja. Toisinaan tekijä vahvistaa sanomaansa (Kauppa nostaa SOK:n kiis- 
tatta maan suurimmaksi päivittäistavarakaupan yhtiöksi noin 42 prosentin markkinaosuudella.) ja toisinaan esittää sanotun vain yhtenä mahdollisuutena tarkastella asiaa (Työttömyys voi sinä aikana kaksinkertaistua nykyisestä viiden prosentin tasosta.). Pääkirjoituksissa on myös lupa ohjeistaa ja arvottaa niin asioita kuin ihmisiä. Asioita arvotettaessa rakennetaan esimerkiksi 'havainnoinnin', 'hallittavuuden', 'hyödyllisyyden', 'tasapainon', 'sosiaalisen merkittävyyden', 'kyettävyyden', 'välttämättömyyden' ja 'mahdollisuuksien vs. uhkien' merkityksiä. Tekijän identiteetin tuottamisessa on kuitenkin myös rajoituksia. Esimerkiksi tekijän omaäänisten tunteiden ilmaiseminen jää vähäiseksi, sillä tekijä asettuu toistuvasti muiden tunteiden tulkiksi. Ihmisiä arvotetaan erityisesti 'kyvykkyyden' ja 'määrätietoisuuden' merkityksillä, yleensä adjektiiveilla ja adverbeilla, jotka selkeästi ovat arvottamiseen vakiintuneita kielellisiä keinoja ja siksi eksplisiittisiksi luokiteltavia. Näiden lisäksi ihmisiä arvotetaan myös 'sopivuuden' merkityksillä.

Kielellisten analyysien perusteella olen lopuksi tehnyt tulkinnan siitä, millainen käsitys pääkirjoituksien, tai tarkemmin sanoen yhden pääkirjoitusten alalajin, kehitystekstien tekijästä syntyy. Taloussanomalehtien pääkirjoituksissa tekijän identiteettiä voi luonnehtia viileäksi talouden ja poliittisten asioiden arvottamiseen keskittyväksi talousalan tuntijaksi, joka varman oloisesti selittää talouden kehityskulkuja ja tarvittaessa spekuloi tai tietää, miten ne etenevät. Analyysin esille tuomat kielelliset valinnat voidaan nähdä myös kuvauksena siitä, miten tässä tekstilajissa merkityksiä voi odottaa tuotettavan jatkossakin.

Pääkirjoitustekstien analyysien perusteella voidaan pohtia myös, miksi teksteihin on valittu juuri ne merkitykset, jotka on valittu. Kontekstin tai toimittajan omaksuman rajatumman sosiaalisen roolin näkökulmasta voidaan väittää, että merkitykset nojaavat ideologisiin taustaoletuksiin. Ne puolestaan ovat yhdenmukaisia pääkirjoitustoimittajien kuvaaman, taloussanomalehdissä jaetun ihanteellisen ideologian kanssa. Taloussanomalehtien kontekstissa talouden ihanteet ovat monesti selkeitä ja laajalti jaettuja. Pääkirjoitustoimittajat kertovat niistä avoimesti, ja tekstit sisältävät selkeitä arvotuksia esimerkiksi siitä, mikä on hyvä ja mikä huono tilanne. Silti tekstianalyysit osoittavat, että taloussanomalehtien pääkirjoituksissa keskitytään mieluummin asioiden kuin ihmisten arvottamiseen. Tämä saattaa johtua siitä, että asioiden arvottamisen oletetaan herättävän lukijoissa vähemmän reaktioita kuin ihmisten arvottamisen. Sosiaalisesti vielä varmempaa on kirjoittaa vain aiheista, jotka eivät ole tulenarkoja. Samalla kun teksteissä arvottaminen kohdistuu erityisesti asioihin, teksteihin tuotetaan kuvaa järkevästä asian tuntijasta ja erottaudutaan ihmisten arvostelemisen käytännöistä. Lukijoiden huomioiminen näkyy teksteissä myös siten, että talouden toimijoiden kyvykkyyttä ja muita ominaisuuksia on hyvä kehua. Lisäksi talouden toimijoita saatetaan ohjeistaa, jotta he osaisivat kehittää toimintaansa kannattavammaksi. Poliitikkoja taas voidaan ohjeistaa, jotta he osaisivat tehdä oikeanlaisia poliittisia tekoja. Jos talouden toimijoita on tarpeen arvostella, nimien mainitsemista voidaan vältellä ja puhua esimerkiksi vain johdosta tai pimeistä voimista. Sen sijaan politiikkoja saatetaan arvostella vapaammin, varsinkin jos he edustavat vasemmistoa.

Kaiken kaikkiaan tietyssä sosiaalisessa roolissa on osattava käyttää kieltä odotusten mukaisesti. Lukijat on vakuutettava. Jokaisessa instituutiossa tai organisaatiossa on 
sitouduttu tiettyihin ideologisiin näkemyksiin, jotka diskurssiyhteisössä toimivat ovat omaksuneet. Mediaorganisaatioissa erityisesti median julkaisemiin sisältöihin liittyvät ideologiset näkemykset ovat yleensä julkilausuttuja lähtökohtia, jotka ovat vastaavan päätoimittajan täsmentämiä. Niitä kutsutaan lehden linjaksi. Koska tutkimukseni keskittyi pääkirjoitusteksteihin ja niissä tuotettuihin merkityksiin, lehden sisältöihin liittyvät ideologiset näkemykset ovat olleet yksi tutkimuksen kohteista.

Pääkirjoitusten tekstilajissa ideologiset taustat ovat varsin avoimesti julkilausuttuja ja vakiintuneita. Tekstilajin kontekstia voi näin ollen kuvailla jossain määrin tarkkarajaiseksi verrattuna moniin sellaisiin tekstilajeihin, joissa ideologisista taustoista vaietaan. Näen, että tämän tutkimuksen yhtenä tehtävänä on tuoda esille tekstin tekijöiden näkemysten, kontekstiin liittyvien ideologioiden ja kielen yhteyksiä. Miltä yhteydet näyttävät jossain toisessa kontekstissa? Missä määrin yhteydet ovat tunnistettavissa ja millaisin menetelmin? Kielentutkijoilla riittää tutkittavaa.

\section{Lähteet}

Bhatia, Vijay K. 1993. Analysing Genre: Language Use in Professional Settings. Lontoo \& New York: Longman.

- 2004. Worlds of Written Discourse. A Genre-Based View. Lontoo \& New York: Continuum.

Fairclough, Norman 2003. Analysing Discourse. Textual analysis for social research. Lontoo \& New York: Routledge.

2006. Language and Globalization. Lontoo: Routledge.

Luukka, Minna-Ritt ta 1995. Puhuttua ja kirjoitettua tiedettä. Funktionaalinen ja yhteisöllinen näkökulma tieteen kielen interpersonaalisiin piirteisiin. Jyväskylä Studies in Communication 4. Jyväskylä: Jyväskylän yliopisto.

Martin, James R. - White, Peter R. R. 2005. The Language of Evaluation. Appraisal in English. Hampshire \& New York: Palgrave Macmillan.

Swales, John 1990. Genre Analysis. English in Academic and Research Settings. Cambridge: Cambridge University Press.

Heli Katajamäki: Tekijän identiteetti taloussanomalehtien pääkirjoituksissa: Pääkirjoitustoimittajan sosiaalisesta roolista tuotettu, teksteistä tulkittu. Vaasan yliopisto. Markkinoinnin ja viestinnän akateeminen yksikkö. Acta Wasaensia 411. Vaasa: Vaasan yliopisto 2018. http://urn.fi/URN:ISBN:978-952-476-833-7.

Kirjoittajan yhteystiedot:

etunimi.sukunimi@uwasa.fi 